\title{
DISZLEXIÁVAL NÉMETÜL
}

Szerzők:

Mályusz Enikő

Debreceni Egyetem Kossuth Lajos

Gyakorló Gimnáziuma és Általános Iskolája

Mező Katalin

Debreceni Egyetem

Első szerző e-mail címe:

nonnaeni@hotmail.com
Lektorok:

\author{
Szalay Kristóf \\ német nyelvtanár \\ Mozgásjavító Általános Iskola \\ Egri Tímea \\ ELTE Bárczi Gusztáv \\ Gyógypedagógiai Kara \\ Varga Imre \\ Szegedi Tudományegyetem \\ Nemes Magdolna \\ Debreceni Egyetem
}

Mályusz Enikő, Mező Katalin (2017): Diszlexiával németül. Különleges Bánásmód, III. évf. 2017/4. szám, 67-75. DOI 10.18458/KB.2017.4.67

\begin{abstract}
Absztrakt
Jelen tanulmány a diszlexiával küzdő tanulók német nyelvtanulásának sajátosságaihoz nyújt újabb információkat a tanulók nyelvi lexikális hálózatának felmérése által. A tanulmányban többek között arra kerestük a választ, hogy milyen jellemző jegyei jelennek meg a diszlexiának az idegen nyelvtanulásban? Valóban minden diszlexiás gyermeket fel kell menteni az idegen nyelvtanulása alól, vagy léteznek olyan utak, melyek elvezethetnek a nyelvtudás kialakulásához? Célunk a magyar anyanyelvü németül tanuló diszlexiások nyelvi tudásának mérése általi tanítási tapasztalatok levonása. Módszer: diszlexiások lexikális hálózatának felmérése szóasszociációs feladattal. Minta: 19 tanulási zavarral küzdő tanulót vizsgáltunk. Következtetés: Vizsgálati eredményeink azt bizonyítják, nem felmenteni kellene a diszlexiával küzdő gyermekeket, hanem az erősségeikre támaszkodva, más úton kellene átadni a tudást.
\end{abstract}

Kulcsszavak: diszlexia, idegen nyelv, fejlesztés, fejlesztőpedagógia

Diszciplina: pedagógia

\begin{abstract}
The current study provides insight into the specificities of dyslexic pupils learning German as a foreign language by measuring their language lexical knowledge. The aim was to explore the nature of dyslexia whilst learning a foreign language. Should we really free all such pupils from the strains of learning a foreign language? Or is it a case of finding the appropriate
\end{abstract}


methodology to learn a new language? The goal is to measure language skills in a foreign language and draw inferences from this. Method: Word association exercises are used to measure the lexical knowledge of children with learning disorders, including dyslexia. Sample: 19 students with learning disorders. Conclusion: The results clearly indicate that we should find pupils' individual strengths and utilise these, instead of simply exempting pupils from learning foreign languages.

Keywords: dyslexia, foreign language, development, developmental psychology

Disciplines: pedagogy

A diszlexia meghatározásának számos formája létezik. A korai kutatók közül Ranschburg (1916, idézi Meixner, 2012. 3.) a következőkkel alapozza meg a definíciót: ,a legasthenia a szellemi szervezetnek az a csökkentértéküsége, melynek következtében a gyermekek normális érzékszervek ellenére sem tudják az első években elsajátítani az olvasást." Később Luchsinger és Arnold (1970) ezt a jellemzést kiegészítette azzal, hogy ,átlagosan intelligens gyermekek veleszületett vagy a korai gyermekkorban szerzett képtelensége arra, hogy az olvasást és írást a szokott módon elsajátítsák." Bryant és Brandley (1985) meghatározásában a diszlexia a részképesség zavarok egyik változata, az írás és az olvasás elsajátításának neurológiai eredetü nehézsége, mely nem magyarázható értelmi fogyatékossággal vagy a megfelelő oktatás hiányáva. Napjaink diszlexia szemlélete annyiban változott, hogy a diszlexiát egyre inkább viszonyfogalomként értelmezik (Meixner, 2012, 3.), s azt tartják, hogy az olvasászavar esetében diszharmónia jelenik meg a gyermekkel szembeni jogos elvárások (pl. a gyerek adottságai); az olvasás-írás tanítására szánt idő és gyakorlási mennyiség; valamint az eredmény között. A legújabb diszlexia meghatározásokban (Christiansen, 2014, Csépe, 2014.) a diszlexiát neurológiai alapon közelítik meg, s a diszlexiát, mint „biogenetikus írási-olvasási nehézségnek" nevezik. Az agy bal frontális lebenyében bizonyos neuronok vele születetten megváltoznak, amelynek következtében egyes részképesség-területeken nem az életkornak megfelelö fejlödés tapasztalható. A nehézségek az olvasás, az írás területén, vagy mindkét területen jelentkezhetnek.

A diszlexia jellemzö tünetei a betütévesztések, betücserék az olvasásban; az olvasási tempó és a szövegértés zavara; az auditív és vizuális információ feldolgozás zavara; a gyenge rövidtávú memória; a sorrendiség, az irányok, a téri orientáció problematikája; a nyelvtani fogalmak megértésének nehézsége stb. (Tánczos, 2007). A diszlexiás tanulóknál mindezek komoly nyelvtanulási nehézséget idézhetnek elő, hiszen nem csak az írás és az olvasás nehezített, de a beszéd és a hallás utáni szövegértés is problémás. Mindezek figyelembe vételével a diszlexiás tanulók számára már 1993 óta (1993. évi LXXIX törvény a közoktatásról 30.§) számos kedvezmény áll rendelkezésre a nyelvtanulás megkönnyítéséhez pl. a teljes felmentés az értékelés alól; az írásbeli teljesítmény értékelése alóli felmentés; a helyesírás értékelése alóli felmentés; többletidő adásának lehetősége.

E törvényt félreértelmezve sokan a kedvezményeket a nyelvtanulás alóli teljes felmentésnek tekintik, s lehetőséget sem adnak arra, hogy a diszlexiás tanulók is örömmel vegyenek részt az idegen nyelvek elsajátításában. Holott a diszlexiások esetében is létezik eredményes idegen nyelvtanulás, bár mindez nagyban függ a nyelvtanítás módjától, a nyelvtanár hozzáállásától és a gyermek motivációjától is.

Jelen tanulmányban a diszlexiával küzdő tanulók idegen nyelvi lexikális hálózatának felmérése által szeretnénk képet kapni a német nyelv taníthatósági struktúrájáról. Tanulmányunkban a kialakulóban lévő lexikon vizsgálata kapott figyelmet, s ennek okán általános iskolás tanulók vizsgálatára került sor. Hagyományos körülmények között a kezdö 
nyelvtanulók szókincse jellemzően fonológiai, azaz hangzásbeli asszociációs alapon szerveződik, mivel a kialakuló szókincskészlet kapcsolatai még nem stabilak (Meara, 1983; Wolter, 2001; Zhang, 2003). Mindemellett az általános iskolások idegen nyelvi lexikájának szerveződésében a föneveknek van döntö szerepe. Kíváncsiak voltunk arra, hogy a diszlexiások szókincsbővítése során is a fonológiai szerveződésére kell építenünk, vagy az adott szó idegen nyelven való felidézését más módszerek alkalmazásával segíthetjük elő? Valljuk, hogy nem felmenteni kell a diszlexiás tanulót a nyelv tanulása alól, hanem a megfelelő utat kell megkeresni a tudás átadására, ehhez keressük a kapaszkodókat jelen tanulmányunkban.

\section{Kutatási minta}

A vizsgálatban 19 fő diszlexiás tanulási zavarral élö tanuló vett részt. A felmérés idején 9-14 évesek; 2 fö ötödik osztályos; 2 fő hatodik osztályos; 4 fő hetedik osztályos; 1 fő nyolcadik osztályos. A tanulók heti kettő, három illetve négy órában tanulnak németül. A minta létszáma alacsony $(\mathrm{N}=19)$, mivel a csoport speciális összetétele miatt- valamennyi tanuló diszlexiával küzd és idegen nyelvet tanul - a mintavétel nehezített. A diszlexiások kis létszámú osztályban tanulják az idegen nyelvet. Ebből következően a kutatásunkban megfogalmazottakat további kutatásokra érdemes tapasztalatoknak tekintjük.

\section{A kutatás módszere}

Kutatásunkban a magyar anyanyelvű németet, mint első idegen nyelvet; illetve az angol mellett, mint második idegen nyelvet tanuló általános iskolások nyelvi tudásának felmérésére került sor több szempontból. A vizsgálat során szóasszociációs teszt (Kohlmann, 2014) kitöltésére, valamint nyelvtanulási problémákat elemző egyéni válaszadásokra került sor. A szóasszociációs teszt négy feladatot tartalmazott: 1) az alapszókincshez tartozó szóasszociációs feladat (ennek bővebb kifejtése jelen tanulmányunk alapja); 2) 12 szó magyarra fordítása; 3) 10-13 szóhoz négy lehetséges válaszból a megfelelő szinonima kiválasztása; 4) tizennégy mondatban a kezdő betű és annyi pont megadásával, ahány betűből áll a szó, maga a szó pótlása.

A feladatok közül az első (az alapszókincshez tartozó szóasszociációs) feladat - melynek célja a tanulók lexikális tudásának, lexikális hálózatának felmérése - a következőképp valósult meg: 8 illetve 12 szóhoz kellett legalább három, legfeljebb öt válaszszót írni. A feladatválasztás célja, hogy minél spontánabb módon válaszoljanak a tanult nyelv valamelyikével a hívó szóra. Arra voltunk kíváncsiak, hogy hány választ vált ki egy-egy mérhető szó, milyen kategóriákba/szófajokba sorolhatóak a válaszszavak, illetve, hogy milyen nyelven adták meg azokat. Emellett az is megfigyelhető, hogy milyen területekröl aktiválják a válaszokat, milyen sorrendben, ezáltal az aktiváció terjedésének útvonala is nyomon érhető. A 8 illetve 12 német nyelvü hívó szó az iskolákban általánosan használt német tankönyvek alapján kerültek összeállításra. A hívószavak kiválasztásánál arra törekedtünk, hogy minél több témához kapcsolódjanak a megadott hívó szavak, növelve ezzel a válaszadás esélyét.

3. évfolyamon a szóasszociációs feladatba 5 fönév $(Z a h l=$ szám, Familie $=$ család, Schule $=$ iskola, Katze $=$ cica, Farbe $=$ szín), 2 ige $($ spielen $=$ játszani, lernen $=$ tanulni) és 1 melléknév (super $=$ nagyszerü $)$ került.

4. évfolyamtól kezdve a 12 szóból 7 főnév $(Z a h l=$ szám, Auge $=$ szem, Familie $=$ család, Schule $=$ iskola, Apfel $=$ alma, Hund $=$ kutya, Farbe $=$ szín $), 4$ ige $($ spielen $=$ játszani, lernen $=$ tanulni, essen $=$ enni, telefonieren $=$ telefonálni $)$ és 1 melléknév (gut = jó) szerepelt a tesztben.

A mért főnevek közül jelen tanulmányban a Familie, Schule fönevek; az igék közül a spielen és lernen szavak kerültek kiértékelésre, mert egyrészt ezek a szavak a 
legáltalánosabban használtak, másrészt ezekre a szavakra érkezett a legtöbb asszociáció a tanulóktól.

A feladat instrukciója a következő volt: „Kérlek, sorolj fel legalább három, legfeljebb öt szót, amelyek az alábbi szavakról bármely nyelven elöször eszedbe jutnak!"

A hívószavak után egy táblázatban öt hely állt rendelkezésre a szóasszociációk számára. A válaszokat bármely tanult nyelven (beleértve az anyanyelvüket is) adhatták meg, mert a vizsgálat célja a szókincsszerkezet feltérképezése volt spontán szófelidézési folyamattal.

A teszt kitöltése a tanítási órákon történt. A válaszadás irányítás/beavatkozás nélkül, spontán valósult meg, melynek eredményeként a tanulók kevés szót javítottak, az első eszükbe jutó gondolatot írták le. A teszt kitöltése 45 percet vett igénybe.

\section{Eredmények bemutatása a kiválasztott két főnév és két ige segítségével}

Az alábbi ábrákon a Familie, Schule fönevek, valamint a spielen és lernen igékre adott asszociációk kerülnek elemzésre. Minden ábrán láthatóak a válaszok számai egy-egy tanulási évre lebontva (azaz, hogy egy, két, három, négy, öt év német nyelv tanulása után hány asszociáció jutott eszükbe a tesztfelvétel idején); valamint megjelenítésre kerülnek az adott szóra adott asszociáció szófajai is (azaz az asszociáció szófaja: ige, főnév, melléknév vagy egyéb).

Az 1. ábrán a Familie főnév szó asszociációi jelennek meg: a diszlexiás tanulók esetében többnyire egyszerü fordítás jelenik meg asszociáció helyett (azaz Familie $=$ család). Csak a két éve nyelvet tanuló csoportban jelent meg ige szófajú asszociáció.

1. ábra. a Familie szó asszociációi. Forrás: Szerzők.

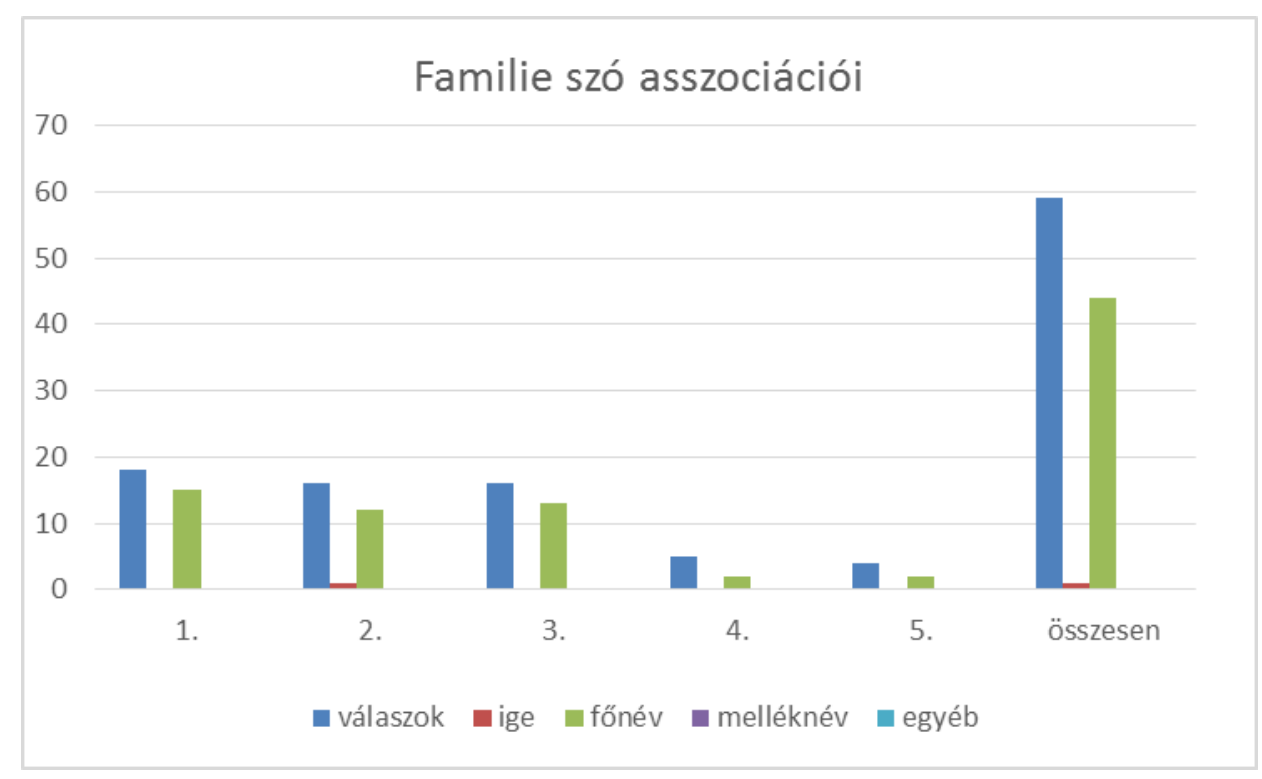

$\mathrm{Az}$ ige használata esetében az otthoni tevékenységet meghatározó szavakat írtak. Az egyszerü fordításon túl időnként a családtagjainak felsorolása is megjelent, ami viszont szintén fönév szófajú.

A Schule - iskola szó (2. ábra) esetében már nagyobb a szórási arány a szófajok tekintetében. Ennél a szónál a téma játszik elsődleges szerepet, a fordítási ekvivalens csak 
második helyen jelentkezik. Megjelentek már az igék és melléknevek is, ami a szó asszociatív fantáziára építő erejét erősítheti.

2. $\quad$ ábra. a Schule szó asszociációi. Forrás: Szerzök.

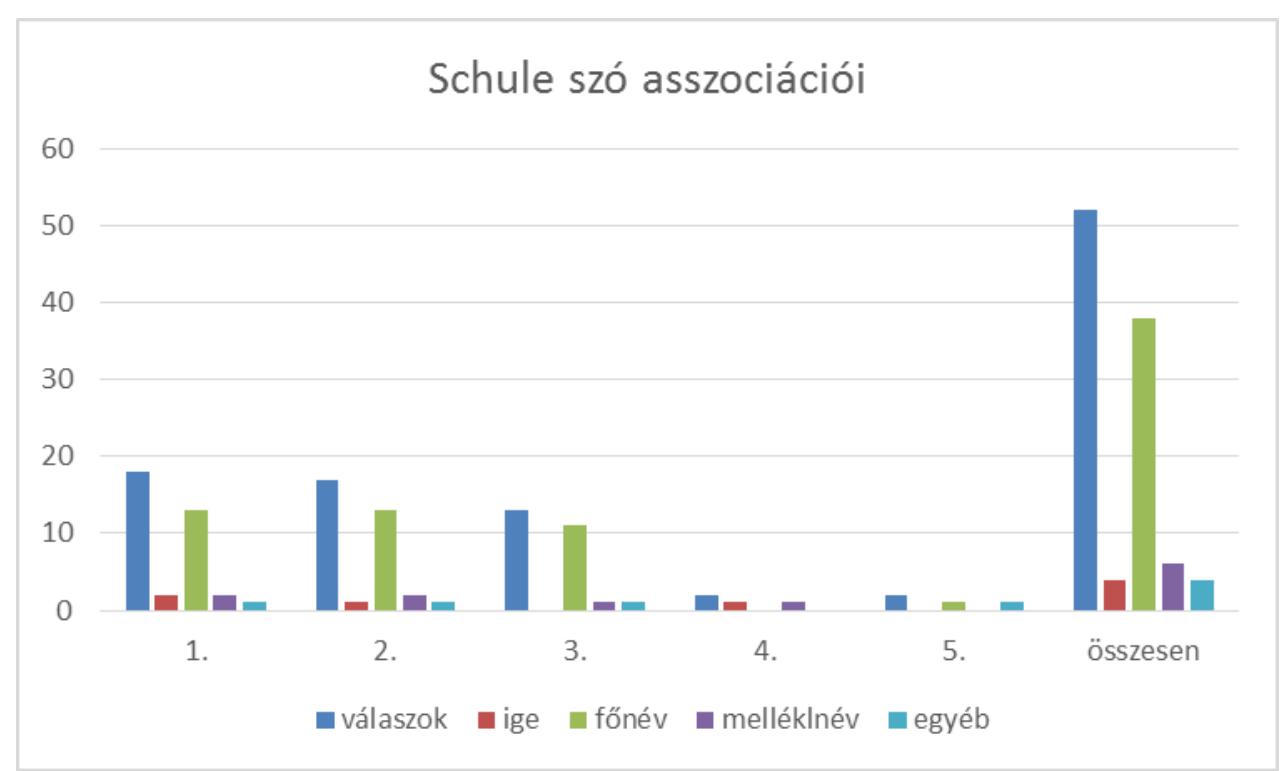

A lernen - tanulni ige (3. ábra) esetében a szóhoz tartozó augmentum lehetőségével éltek leggyakrabban a gyermekek. Felsorolták mi mindent lehet megtanulni (verset, mondókát, párbeszédet, szavakat, kifejezéseket, tantárgyakat), persze néhányan az unalom, nehéz, nem jó szavakkal asszociáltak.

3. ábra. a lernen szó asszociációi. Forrás: Szerzök.

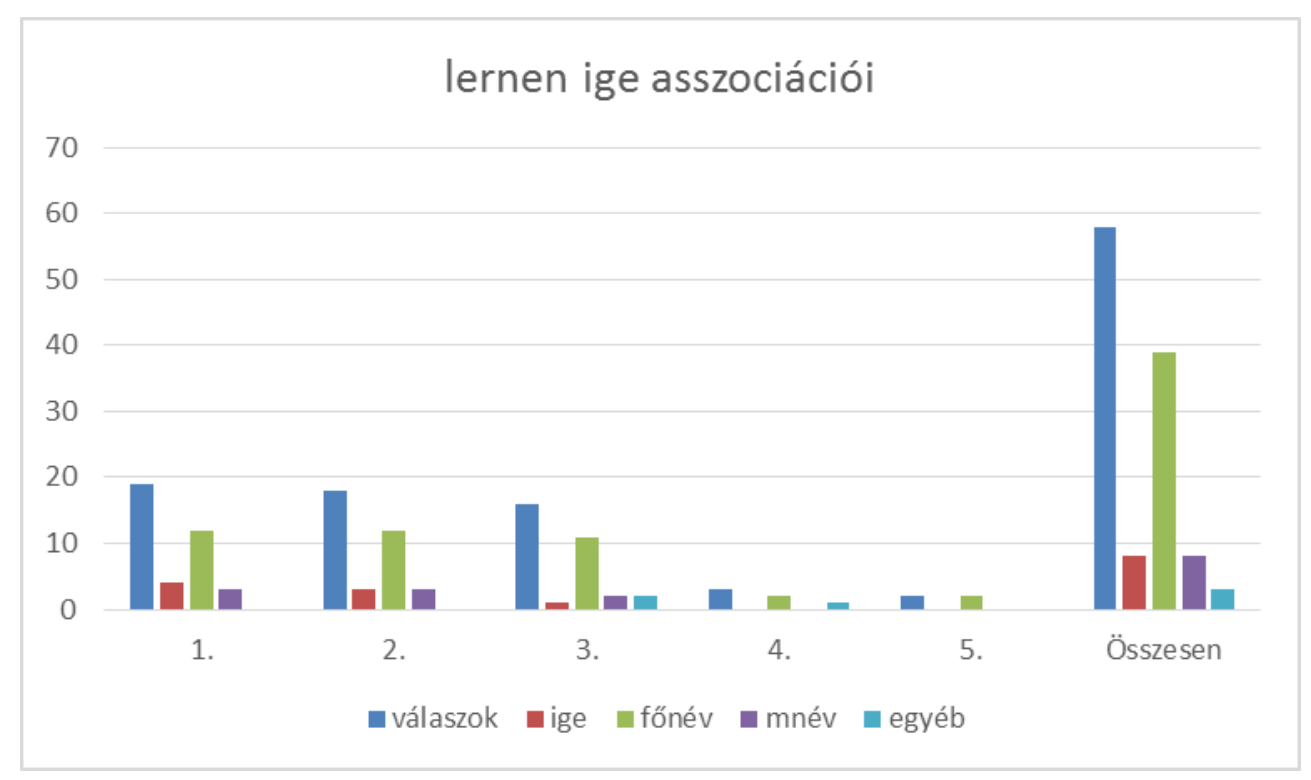

A spielen - játszani ige (4. ábra) esetében egyenlő arányban szerepel a fordítási ekvivalens a téma augmentumával. Nagyon sok labdajátékot (Fußball, Basketball, Volleyball) említenek a tanulók, talán a tankönyvi tananyag miatt. Vagy azért, mert ezekkel szeretnének játszani. 
Melléknevek is megjelennek a jó, nagyszerü szavak kíséretében. Főnevek közül a labdajátékok mellett a szórakozás szinonimái jelennek meg.

4. ábra. a spilen szó asszociációi. Forrás: Szerzök.

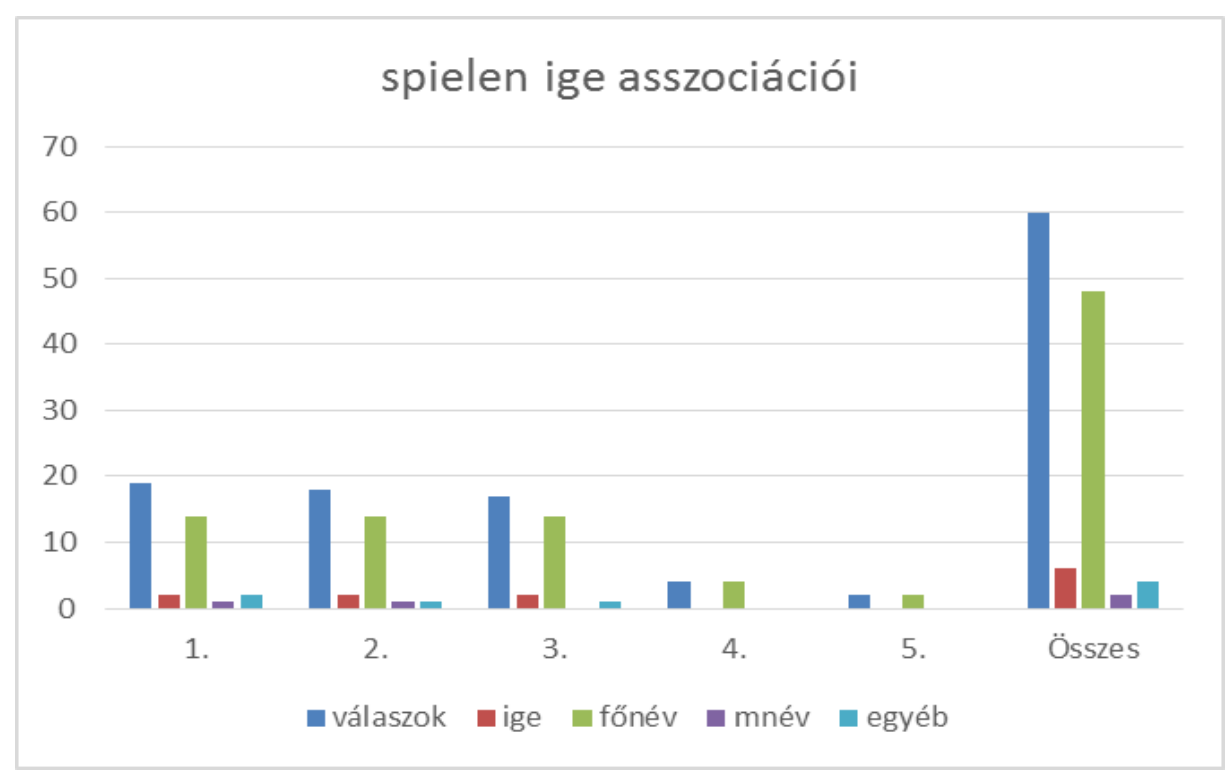

A teszt további feladataiban egy-egy szó fordítására került sor, majd a passzív szókincs teszteltelésére a szinonimák keresésével került sor. Végül az aktív szókincsvizsgálat következett mondatokban történő szópótlás segítségével.

\section{A nyelvtanulási problémákat elemző egyéni válaszadások eredményei}

A tanulók az egyéni válaszadásaiból az alábbi problémaleltárat lehet összeállítani:

1. Az angol nyelv tanulását a diszlexiás tanulók könnyebbnek érzik a német nyelvnél, melynek okait hasonlóan fogalmazták meg, mint a nem diszlexiások:

- „Az angol nyelvet könnyebben meg tudom tanulni, mert könnyebb a nyelvezete."

- „A németet a kiejtés és a névelök miatt nehezebben tudom megtanulni."

- „Az angol könnyebben megy; egyszerübb kiejteni a szavakat, a nyelvtana is egyszerübb. Könnyebb a névelők használata."

- „Nagyon sokban különbözik a két nyelv: eleve az angol egy egyszerübb nyelv. Míg a németben más mindennek a szabálya. Ragozásban is tele van kivétellel, plusz a der, die, das."

- „A mondatok felépítése a szavak kiejtése is nehéz, az angolban kevés az olyan szabály, amelyben kivétel van."

- „A szavak tanulása unalmas”

2. Több segítséget, kapaszkodót várnának a német nyelvtanulás segítéséhez:

- „Segít az, hogy órán a szótárfüzetbe a der-t kékkel a die-t pirossal és a das-t zölddel jelöljük. Ez sokat segít."

- „Segít az, hogy órán színekkel jelöljük a névelöket.”

- „Segítenek, ha a szavakat mozgással kísérjük.”

- „Jók a játékok” 


\section{Megvitatás}

A szóasszociációs teszt eredményeinek elemzése mennyiségi és minőségi szempont alapján történt. Mennyiségi szempontból vizsgáltuk, hogy, milyen arányban és hányan aktiváltak igét, konkrét fönevet, elvont fogalmat vagy melléknevet, valamint hányan éltek a lehetséges öt spontán válaszadás valamelyikével. Mennyiségi szempontból vizsgálva az asszociációs feladatot, megállapítható, hogy a diszlexiás tanulók csak a minimumra törekedtek. A legalább három szót beírták, legfeljebb ötöt már nem. Ez akár a szókincsük mennyiségi hiányára is utalhat

Minőségi szempontból azt elemzetük, hogy hányan éltek az asszociáció során első helyen fordítással, mivel a hazai tanulmányok (Dóczi, 2006). azt bizonyítják, hogy a fordítási ekvivalensek az alacsonyabb idegennyelvtudás-szinthez kapcsolódnak. Saját tapasztalataink is azt bizonyítják, hogy diszlexiások erős kapcsolatokat építenek ki a szavak és magyar jelentésük között a szótanulás megkönnyítésére. Ennek ismerete azért fontos, mert ez a tanulási stratégiák kiépítése során segítséget jelenthet pl. a memóriamankók, mnemotechnikák megalapozása során. A kezdő szinten álló diszlexiás nyelvtanulók több fordítási ekvivalenst aktiválnak, azonban mind a lernen, mind a spielen igének van téma augmentuma, a csoport ezt aktiválta a leggyakrabban. Mindkét igénél a fölérendelő összefoglaló kifejezések a második legerősebb kategória. Harmadik helyen a fordítási ekvivalens áll. Gyakran a konkrét tartalmakhoz kötődő eszközöket, funkciókat aktivizáltak a tanulók.

A tanulók többsége konkrét fordítást adott a szóasszociációs teszt során. Majd a következő oszlopokban a dologra jellemző tulajdonságot írta le. Egy tanuló talán félreértette az asszociáció szó fogalmát, s azonos mássalhangzókkal kezdődő szavakat írt a feladat minden sorába. Mivel szabad használat volt a tanult nyelveket illetően, így sokan csak magyar szavakat írtak be. A vizsgált csoportban megfigyelhető volt, hogy a diszlexiára utaló jegyek a német szavak esetében is megjelentek például vizuális hasonlóság miatt az azonos alakú vagy hasonló betükből álló szavak jelentését keverték (Mädchen - Mäppchen, Kreide - Kinder, Schwester - schwarz, Geschwister - Schwester stb.). Gyakran a magyar hang-betü kombinációját használják írás közben: például Vater ejtsd Fater. A kiejtés szerinti írás nagyon jellemző a diszlexiás tanulókra. Valamint az is jellemző, hogy arányaiban több magyar válasz adtak, mint német nyelvüt.

A német nyelvben a magyar nyelvhez hasonlóan magasabb a graféma-fonéma megfelelés aránya, mint például az angol nyelvben, a németül tanuló diszlexiás diákok a szavakhoz, fogalmakhoz kötődő sokrétü információt nehezebben aktiválják, erősebben kötődnek a lexikális kifejezésekhez, azaz a fogalmi feldolgozásuk alacsonyabb szinten történik.

A hangzásbeli asszociáció csak két diszlexiás tanuló esetében volt domináns, a többiek esetében a szituatív eszközkategória használata volt jellemző. Ebből az is következik, hogy az auditív, hangoztató tanítási módszerek egyedüli használata a diszlexiás tanulók esetében nem feltétlenül eredményes.

A vizsgálati eredmények azt is elővetítik, hogy sokkal több játékosságot, kreativitást igénylő feladatok alkalmazásával kell oktatni a tanulási zavarral küzdő tanulókat. A diszlexiás tanulók rövidtávú és munkamemóriája gyengébb, ez pedig megnehezíti a szótanulásukat. Mondhatnánk azt is (ahogyan ők is megfogalmazták), kifejezetten szenvedés és unalmas számukra a szótanulás. A befektetett energia nem hozza meg a várt eredményt. Gyakran nem emlékeznek a megtanult szavakra, vagy más szavakkal összekeverik azokat, esetleg félreolvasott szavakat jegyeznek meg. Mindezek ellenére a diszlexiás tanulók idegen nyelv tanulása eredményessé tehető, csak speciális tanítási/ tanulási eljárások alkalmazásával kell 
törekedni az optimális tanulási állapot elérésére. Nézzünk erre vonatkozóan néhány a német nyelv tanítása során is eredményes módszert:

1. Zenés videók, karaoke programok segítségével szavak tanulása,

2. Tabello használata, ahol a tanuló saját és idegen nyelven is látja a szöveget, s annyiszor hallgatja meg, ahányszor akarja. A tananyag rövid mondatokból áll.

3. Új szavak mellé rajzolás, valamely jellegzetes, szóra jellemző dolgot.

4. Szavakkal való játék is segíthet a memorizálásban, pl. memóriajáték.

5. Memóriamankók, mnemotechnikák (Mező, 2011) használata.

6. Speciális tanulási stratégiák alkalmazásának előnyben részesítése (ld. Mező-IPOO tanulásfejlesztési eljárás, Mező, 2011).

7. Karikatúrák, képregények használata (Szalay, 2016).

8. Névelö begyakorolására színek és mozgásos játékok használata. Pl. Felállsz, ha der, leguggolsz, ha die, hátrafordulsz, ha das a névelője a németül mondott szónak. De lehet tapsolni, koppintani, dobbantani stb.

9. Dalok, mondókák, versek, mesék gyakori használata.

10. Drámatechniákkal kísért kommunikáció. Helyzet- és szituációs gyakorlatok, történetek.

11. Diktafon, okos telefon a visszamondás, visszahallgatás segítése érdekében.

12. Számítógépes programok. Szövegszerkesztő és helyesírásellenőrző programok használata. Nyelvtanuló- és nyelvgyakorló programok.

\section{Konklúzió}

A diszlexiás tanulók esetében is van lehetőség az idegen nyelv tanítására, azonban nemcsak a képességekre kell alapozni, hanem a szükségszerü a fokozott motiváció. Az optimális feszültségi szint fenntartására szükséges, amit cask megfelelő ráhangolással lehet elérni. A német nyelv tanítása során figyelembe kell venni, hogy a kezdő diszlexiás nyelvtanulók szókincse elődlegesen nem az asszociációs szerveződésen, hanem a közvetlen tapasztalaton, az elsődleges fordításon alapszik, emellett a föneveken alapuló értelmezés hangsúlyos. Erre alapozva lehet elkezdeni a diszlexiás tanulók sikeres nyelvtanulását, meg kell keresni minden tanuló esetében az erősségeket, a kapaszkodó pontokat az asszociációk beindításához, $\mathrm{s}$ arra támaszkodva lehet fejleszteni a tanulók nyelvismeretét.

\section{Irodalom}

Bryant, P., \& Bradley, L. (1985): Children's reading problems. Basil Blackwell, London.

Christiansen, A. (2014): Az írás-olvasási és számolási zavarok kezelése. Saxum Könyvkiadó, Budapest.

Csépe, V. (2014) Az olvasás zavarai és a diszlexia. In: Pszicholingvisztika. Akadémiai Kiadó, Budapest, pp. 1325-1343

Dóczi, B. (2006): Mapping the mental lexicon of pre-intermediate learners; word associations in a depth of word knowledge elicitation task. In: Horváth, J. Nikolov, M. (szerk.): UPRT 2007: Empirical studies in English applied linguistics, University of Pécs Roundtable, 117-138.

Kohlmann Á. (2014): Diszlexiások/diszgráfiások anyanyelvi és idegen nyelvi szókincsszerkezete. Pázmány Péter Katolikus Egyetem Nyelvtudományi Doktori Iskola. Budapest.

Luchsinger, R.és Godfrey E. Arnold (1970).The voice and its Disorders. Manual of Voice and speech Medicine.Vienna, Springer Publishing.

Meara, P. (1983): Word associations in a foreign language. Nottingham Linguistic Circular, 11(2): 29-38. 
Meixner Ildikó (2012): A dyslexia prevenció, reedukáció módszere. Meixner alapítvány, Budapest.

Mező F., Mező K., Mező L.,(2011). Tanulógép, Tanulás módszertani javaslatok. K+F Stúdió Kft., Debrecen.

Mezö, F.(2011): Tanulás: diagnosztika és fejlesztés az IPOO modell alapján. K+F Stúdió Kft. Debrecen.

Szalay K. (2016): Nyelvtanulás karikatúrákkal és képregényekkel. Különleges Bánásmód, II. évf., 2016/1. szám, 73-85.

Tánczos J. (2007): Nyelvtanulás és diszlexia. Pedellus Tankönyvkiadó. Debrecen.

Wolter, B. (2001): Comparing the L1 an L2 mental lexicon. Studies in Second Language Acquisition, 23: 41-69

Zhang, S. (2003): Response types and lexical acquisition.Foreign Language Teaching and Research, 4: 275-281.

http://tabello.com/

http://janus.ttk.ptl.hu/tamop/tananyagok/nyelv_elsajatitas/21_nyelvelsajatitasi_elmeletek.html 